Journal of Biotechnology and Strategic Health Research

\author{
Research Article / Araştırma Makalesi
}

http://dergipark.org.tr/tr/pub/bshr

\title{
Investigation of The Relationship Between Pelvic Girdle Pain and Interpubic Distance
}

\section{Pelvik Halka Ağrısı ile İnterpubik Mesafe Arasındaki İlişkinin İncelenmesi}

\section{(D) Elif Terzi ${ }^{1}$, (DD $ه$ Özgür Kaya ${ }^{2}$}

${ }^{1}$ Dept. of Gynecology And Obstetrics, Private Lokman Hekim Hospital, Ankara, Turkey

${ }^{2}$ Dept. of Orthopedics and Traumatology, Private Lokman Hekim Hospital, Ankara, Turkey

ORCID ID: Elif Terzi https://orcid.org/0000-0001-9809-0494, Özgür Kaya https://orcid.org/0000-0003-2033-9020

*Sorumlu Yazar / Corresponding Author: Dr. Özgür Kaya, e-posta / e-mail: dr.ozgurkaya@yahoo.com

Geliş Tarihi / Received : 28-02-2021

Kabul Tarihi / Accepted: 31-03-2021

Yayın Tarihi / Online Published: 30-04-2021

Terzi E., Kaya Ö. Investigation Of The Relationship Between Pelvic Ring Pain And Interpubic Distance,

J Biotechnol and Strategic Health Res. 2021;5(1):71-77

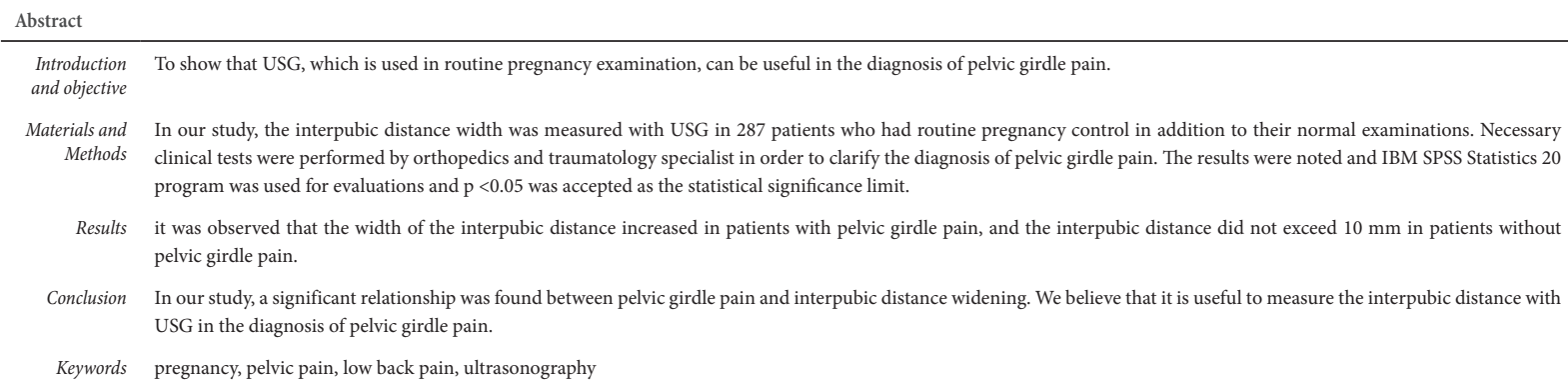

Results it was observed that the width of the interpubic distance increased in patients with pelvic girdle pain, and the interpubic distance did not exceed 10 mm in patients without pelvic girdle pain.

Conclusion In our study, a significant relationship was found between pelvic girdle pain and interpubic distance widening. We believe that it is useful to measure the interpubic distance with USG in the diagnosis of pelvic girdle pain.

Keywords pregnancy, pelvic pain, low back pain, ultrasonography

Özet

Amaç Rutingebe muayenesinde kullanılan USG nin pelvik halka ağrısı tanısında fayda sağlayabileceğini göstermektir

Materyal ve Calısmamizda rutin gebelik kontrolü yapılan 287 hastanın normal muayenelerine ek olarak USG ile interpubik mesafe genisliği ölçüldü. Pelvik halka ağrısı tanısı netlestirilmesi açısından Ortoped

Metod ve Travmatoloji Uzmanı tarafindan gerekli klinik testleri yapıld. Sonuçlar not edildi ve değerlendirmelerde IBM SPSS Statistics 20 programı kullanıldı ve istatistiksel anlamlilk stnırı olarak $p<0,05$ kabul edildi.

Bulgular Pelvik halka ağrısı bulunan hastalarda interpubik mesafe genişliğinin arttığı, pelvik halka ă̆rısı olmayan hastalarda interpubik mesafenin 10mm üzerine çıkmadı̆̆ı gözlendi.

Sonuç Çalş̧mamızda pelvik halka ağrıst ile interpubik mesafe genişlemesi arasında anlaml ilişki saptanmış olup; pelvik halka ağrısı tanısında usg ile interpubik mesafe ölçümü yararlı olduğu kanaatindeyiz.

Anahtar

Kelimeler

gebelik, pelvik ağrı, bel ağrist, ultrasonografi 


\section{INTRODUCTION}

During pregnancy, which is a normal physiological process, the musculoskeletal system is affected as well as all systems of the body. Therefore, pain that can be seen during pregnancy and can sometimes be permanent after birth occurs, and it may affect the patient's quality of life and daily activities ${ }^{1,2}$.

Low back pain and pelvic area pain are the most common musculoskeletal disorders during pregnancy. In some studies, it has been stated that it can be seen up to $80 \%$ during pregnancy ${ }^{3}$. Although low back pain and pelvic girdle pain during pregnancy are usually intertwined situations, they should be distinguished from each other.

Pelvic girdle means that symphyseal joint, sacroiliac joint, iliac bone and sacrum.Pelvic girdle pain is defined as the pain that can spread to the thighs and buttocks; felt in all pelvic bones, including sacroiliac joint, gluteal folds and especially the posterior iliac crest $^{4}$. This terminology proposed for pelvic musculoskeletal pain exclude gynecological and/or urological disorders. It causes restrictions in activities such as standing, walking and sitting. It has been reported that its incidence in pregnant women is up to $20 \%{ }^{4}$. It occurs during pregnancy can continue after birth. Among the etiology of pelvic girdle pain; hormonal, biomechanical, traumatic, genetic and degenerative factors can play a role ${ }^{5,6}$.

Pelvic girdle pain is a condition that is generally ignored and not treated by clinicians and can cause permanent postpartum problems ${ }^{7}$. It has been shown that identification and treatment in early pregnancy is beneficial and reduces workforce loss ${ }^{8}$. Pelvic girdle pain should generally be done with a multidisciplinary team. Treatment of pelvic girdle pain should usually be done with a multidisciplinary team. The treatment protocol should include activity modification, prevention of acute exacerbations, orthoses for pelvic and lumbar support, exercise, and physiotherapy'.
Since the pregnant, fetus and pregnancy should be protected, imaging methods can be used limitedly in the diagnosis of pelvic girdle pain as in other diseases in pregnancy. Anterior posterior radiography of the pelvis helps to reveal symphyseal dissociation and degeneration and cortical irregularities, but it is not recommended because of the effect of ionizing radiation on the fetus. MR imaging can be recommended during pregnancy to identify bone marrow and soft tissue changes. Ultrasonography can be used to detect the disease and to follow its progression ${ }^{6}$.

In our study, in patients diagnosed with pelvic girdle pain, the interpubic distance relationship was evaluated with USG, and it was shown how routine ultrasonography can help in the diagnosis of Pelvic Girdle Pain during pregnancy follow-up.

\section{MATERIAL and METHOD}

The study was approved by the Lokman Hekim University Ethics Committee (2020/063-2020059) on 21/08/2020 and it was carried out in accordance with the Helsinki Declaration of Principles. 287 patients who applied to Gynecology and Obstetrics Clinic for routine pregnancy follow-up were included in the study. All patients included in the study accepted by signing the informed consent form. The patients included in the study were between 6-40 weeks of gestation and their ages between 18-39 years. Patients with previous pelvic or lumbar trauma or surgery were excluded.

Routine USG was performed by the obstetrician for each patient included in the study, and then interpubic distances were measured with the same USG device. Interpubic distance width was measured from the upper corners of the symphyseal joint as described by Björklund et al. ${ }^{10}$ (Figure 1,2). Gravity-parity, age, gestational week and interpubic distance measurements of the patients were noted. Patients with low back and hip pain were referred to an Orthopedics and Traumatology specialist in order to distinguish it from pelvic girdle pain. 
The patients were evaluated by an Orthopedics and Traumatology specialist. The diagnosis of pelvic girdle pain was clarified with the clinical tests described by Albert et al. ${ }^{11}$ and pain was accepted as positive. The diagnosis of pelvic girdle pain was made in the patients whose posterior pelvic provocation pain test that has high specificity, Patrick's Fabere test, palpation of the pubic symphysis, Trendelenburg test and Mennell's test were positive.

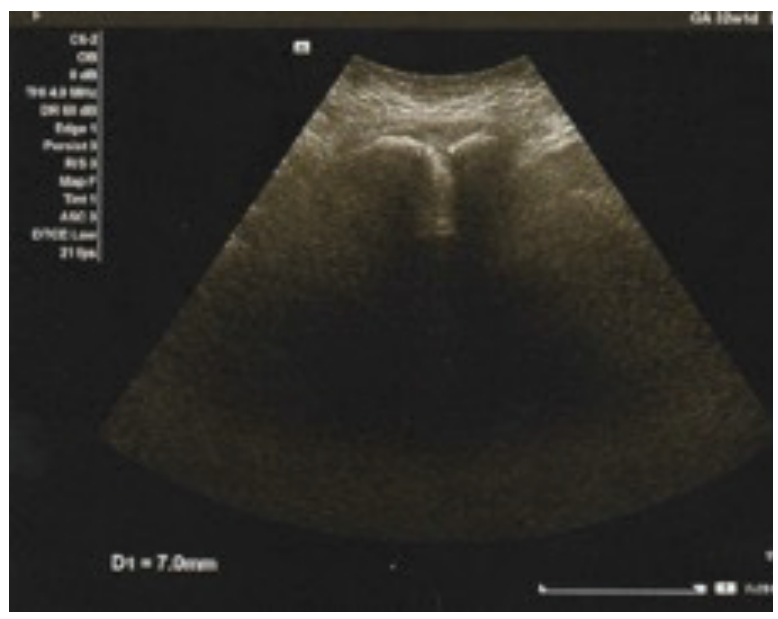

Figure 1. 32 weeks pregnant woman without pelvic pain; the interpubic distance was measured as $7 \mathrm{~mm}$.



Figure 2. 29 weeks pregnant woman with pelvic pain; the interpubic distance was measured as $11.1 \mathrm{~mm}$.

\section{Statistical Analysis}

Mean Standard Deviation, Median, Minimum, Maximum values were given in descriptive statistics for continuous data, and number and percentage values were given for discrete data. Kolmogorov-Smirnov test was used to examine the conformity of the data to normal distribution.

Mann Whitney U test was used to compare the pain status with continuous data.

Spearman Correlation coefficient was used to examine the relationships between continuous data.

Chi-square test was used for group comparisons (cross tables) of nominal variables.

IBM SPSS Statistics 20 program was used for evaluations and $\mathrm{p}<0.05$ was accepted as the statistical significance limit.

\section{RESULTS}

The ages of 287 pregnant women included in the study ranged from 18 to 40 years of age and the average age was found as $26.13 \pm 5.02$. The median gestational week of the pregnant women (Median) was 26 (6-40) weeks and the median gestational number was 2 (1-4). The mean interpubic distance of all pregnant women included in the study was $6.49 \pm 1.95$ (Table 1 ).

\begin{tabular}{|c|c|c|}
\hline & Mean \pm SD & Median (Min-Max) \\
\hline Age & $26.13 \pm 5.02$ & $26(18-39)$ \\
\hline Gestational week & $24.28 \pm 9.88$ & $26(6-40)$ \\
\hline $\begin{array}{l}\text { Number of preg- } \\
\text { nancies }\end{array}$ & $1.63 \pm 0.72$ & $2(1-4)$ \\
\hline Interpubic distance & $6.49 \pm 1.95$ & $6.1(3-12.7)$ \\
\hline
\end{tabular}


Pelvic girdle pain was detected in $18.5 \%$ of the pregnant women included in the study (Table 2).

Table 2. Pelvic girdle pain distributions of pregnant women

\begin{tabular}{|l|c|c|}
\hline & $\mathrm{N}$ & $\%$ \\
\hline Pelvic girdle pain & & \\
\hline NO & 234 & 81.5 \\
\hline YES & 53 & 18.5 \\
\hline
\end{tabular}

There was no difference between the age values of pregnant women with and without pelvic girdle pain ( $\mathrm{p}>0.05)$. The median gestational week of those without pelvic girdle pain was 24 (6-40), and 28 (8-38) of those with pain. There was a difference between the gestational weeks of the patients with and without pain $(\mathrm{p}<0.05)$. The gestational weeks of those with pain were significantly higher than those without pain.

There was no difference between the number of pregnancies with and without pelvic girdle pain ( $p>0.05)$.

The mean interpubic distance was found to be $5.80 \pm 1.23$ in those without pelvic girdle pain, and $9.53 \pm 1.63$ in pregnant women with pain. There was a difference between the Interpubic distance values of those with and without pain ( $\mathrm{p}<0.001$ ). Interpubic distance values of those with pain were significantly greater than those without pain (Table 3).

There was a difference between the rates of interpubic distance values of being $<6 \mathrm{~mm}, 6-10 \mathrm{~mm}$ and $>10 \mathrm{~mm}$ in pregnant women with and without pain $(\mathrm{p}<0.001)$.

Interpubic distance in $44.7 \%$ of the pregnant women included in the study was less than $6 \mathrm{~mm}$, in $44.6 \%$ of them was between $6-10 \mathrm{~mm}$ and in $7.7 \%$ of them was over 10 $\mathrm{mm}$ (Table 4).

The rates of interpubic distance values being over $10 \mathrm{~mm}$ in pregnant women with pain were significantly higher than those without pain, and the rates being below $6 \mathrm{~mm}$ were significantly lower (Table 5).

There was no correlation between interpubic distance $(\mathrm{mm})$ values and age and pregnancy numbers $(\mathrm{p}>0.05)$.

A positive correlation was found between the Interpubic distance values of the pregnant women and the weeks of gestation $(r=0.427 \mathrm{p}<0.001)$. As the week of gestation increases, the Interpubic distance values also increase (Table 6).

\begin{tabular}{|c|c|c|c|c|c|}
\hline \multirow[b]{2}{*}{ Pelvic Girdle Pain } & \multicolumn{2}{|c|}{ NO $(n=234)$} & \multicolumn{2}{|c|}{ YES $(n=53)$} & \multirow[b]{2}{*}{$\mathrm{p}$} \\
\hline & Mean. $\pm S . D$ & $\begin{array}{c}\text { Median } \\
\text { (Min-Max) }\end{array}$ & Mean.. S.D & $\begin{array}{c}\text { Median } \\
\text { (Min-Max) }\end{array}$ & \\
\hline Age & $26.16 \pm 5.17$ & $26(18-39)$ & $26.00 \pm 4.34$ & $26(19-37)$ & 0.952 \\
\hline Gestational Week & $23.62 \pm 10.05$ & $24(6-40)$ & $27.15 \pm 8.82$ & $28(8-38)$ & 0.027 \\
\hline $\begin{array}{l}\text { Number of Preg- } \\
\text { nancies }\end{array}$ & $1.65 \pm 0.72$ & $2(1-4)$ & $1.53 \pm 0.67$ & $1(1-4)$ & 0.270 \\
\hline Interpubic distance & $5.80 \pm 1.23$ & $5.8(3-12.7)$ & $9.53 \pm 1.63$ & $9.7(5.4-12.6)$ & $<0.001$ \\
\hline
\end{tabular}


Table 4. Distribution of the rates of interpubicdistance values being $<6 \mathrm{~mm}, 6-10 \mathrm{~mm}$ and $>10$ in pregnant women

\begin{tabular}{|l|c|c|}
\hline & $\mathrm{n}$ & $\%$ \\
\hline Interpubic distance & & \\
\hline$<6 \mathrm{~mm}$ & 137 & 44.7 \\
\hline $6-10 \mathrm{~mm}$ & 128 & 44.6 \\
\hline$>10 \mathrm{~mm}$ & 22 & 7.7 \\
\hline
\end{tabular}

Table 5. Comparison of the rates of interpubic distance values of $<6 \mathrm{~mm}, 6-10 \mathrm{~mm}$ and $>10$ in pregnant women with and without pelvic girdle pain

\begin{tabular}{|l|c|c|c|c|c|}
\hline Pelvic Girdle Pain & \multicolumn{2}{|c|}{ NO $(\mathrm{n}=234)$} & \multicolumn{2}{|c|}{ YES $(\mathrm{n}=53)$} & \multirow{2}{*}{$\mathrm{p}$} \\
\cline { 1 - 5 } Interpubik distance & $\mathrm{N}$ & $\%$ & $\mathrm{n}$ & $\%$ & \\
\hline$<6 \mathrm{~mm}$ & 136 & 58.1 & 1 & 1.9 & \multirow{2}{*}{$<0.001$} \\
\cline { 1 - 5 } $6-10 \mathrm{~mm}$ & 96 & 41 & 32 & 60.4 & \\
\hline$>10 \mathrm{~mm}$ & 2 & 0.9 & 20 & 37.7 & \\
\hline
\end{tabular}

Table 6. Relationship between Interpubic distance values of pregnant women and gestational week, number of pregnancies and age values (correlation)

\begin{tabular}{|l|c|c|}
\hline & \multicolumn{2}{|c|}{ Interpubic distance $(\mathrm{mm})$} \\
\hline & $\mathrm{R}$ & $\mathrm{P}$ \\
\hline Age & -0.037 & 0.531 \\
\hline Gestational week & 0.427 & 0.000 \\
\hline Number of pregnancies & -0.057 & 0.338 \\
\hline
\end{tabular}

\section{DISCUSSION}

Pelvic girdle pain is a musculoskeletal disease in pregnancy. Analgesics, physiotherapy, pelvic support orthosis, acupuncture can be used in its treatment. Clinical tests are mostly used in the diagnosis phase. Because, imaging methods cannot be used sufficiently for the continuation of healthy pregnancy and protection of fetus health.

In our study, we investigated how effective the USG, which is used routinely in pregnancy follow-up, can be used in the definition of pelvic girdle pain. Therefore, we aimed to detect patients with pelvic girdle pain and having enlargement of the interpubic distance on USG imaging. In patients applying for pregnancy control, after routine examinations, interpubic distance was measured with USG, pain complaints were questioned, and the diagnosis of pel- vic girdle pain was clarified by an Orthopedics and Traumatology specialist.

Among the mechanisms of occurrence of pelvic girdle pain, relaxation in the pelvic joints caused by the relaxin hormone secreted during pregnancy is shown as the main reason in most studies ${ }^{12,13}$. We thought that in patients with pelvic girdle pain, the interpubic distance due to relaxation in the symphyseal joint can be measured as wider. Previously, Björklund et al. ${ }^{14}$ have found that pelvic girdle pain and symphyseal distension were significantly associated in their study in 2000. In their study conducted in 2001, Schollner et al. ${ }^{15}$ has determined the mean interpubic distance as $4 \mathrm{~mm}$ in non-pregnant patients, $6.3 \mathrm{~mm}$ in pregnant women without symphyseal pain and $9.5 \mathrm{~mm}$ and more in pregnant women with symptomatic symphyseal pain.

In our study, interpubic distance was measured by ultrasound in all patients who applied for routine pregnancy follow-up, and the diagnosis of pelvic girdle pain in patients who described pain was clarified by clinical tests. $18.5 \%$ of the patients included in the study had pelvic girdle pain. When the literature was searched, it was observed that this rate was in line with the mean and this shows that the selected clinical tests are appropriate. The interpubic distance was less than $6 \mathrm{~mm}$ in only $1.9 \%$ of patients with pelvic girdle pain. The interpubic distance was greater than $10 \mathrm{~mm}$ in only $0.9 \%$ of the patients without pain. In our study, we did not find a significant relationship between the number of pregnancies and the interpubic distance. We found that as the week of gestation increased, the interpubic distance also increased. Therefore, we think that the width of more than $10 \mathrm{~mm}$ in patients without pain is due to the advanced gestational week. This thought is also supported by the study conducted by Bahlmann et al. ${ }^{16}$ in 1993, since they detect of $3 \mathrm{~mm}$ physiological enlargement in the interpubic distance during normal pregnancy. The interpubic distance measurement was above 10 $\mathrm{mm}$ in $37.7 \%$ of the patients with pelvic girdle pain. The 
interpubic distance was between $6-10 \mathrm{~mm}$ in $60.4 \%$ of patients with pelvic girdle pain. The fact that the number of cases in our study is high by looking at the studies on pelvic girdle pain and symphyseal joint enlargement makes it worthwhile. In addition, the evaluation of each of the USG measurements and clinical tests by the same practitioners to all patients provided standardization. However, we believe that when evaluating the symphyseal joint in pelvic girdle pain, in addition to the width of the interpubic joint distance, the evaluation by elastography in order to detect joint degeneration will contribute.

It was observed that patients with pelvic girdle pain had a significant widening in interpubic distance measurements. We observed a regression in complaints in patients with pelvic girdle pain when conservative treatment such as pelvic belt was applied. Therefore, we believe that measuring interpubic distance with ultrasound is useful in the diagnosis of pelvic girdle pain.

In our study, the relationship between pelvic girdle pain and increased interpubic distance width in ultrasound measurement was found to be significant. Thus, we believe that measuring interpubic distance with USG accompanied by clinical tests will help in the diagnosis of pelvic girdle pain. Clarification of the diagnosis of pelvic girdle pain will enable more accurate treatment selection for the patient and will prevent a decrease in workforce and quality of life.

\section{DECLARATION}

The authors warrant that they do not have any financial and personal relationships with other people, or organizations, that could in appropriately influence (bias) this study. And no conflict of interest. 
J Biotechnol and Strategic Health Res. 2021;5(1):71-77

TERZI, KAYA, Interpubic Distance In Pelvik Pain

\section{References}

1. Sumilo D, Kurinczuk JJ, Redshaw ME, Gray R. Prevalence and impact of disability in women who had recently given birth in the UK. BMC Pregnancy Childbirth 2012;12:31. https://doi.org/10.1186/1471-2393-12-31

2. Paul JA, van Dijk FJ, Frings-Dresen MH. Work load and musculoskeletal complaints during pregnancy. Scand J Work Environ Health 1994;20:153-9.doi:10.5271/sjweh.1414

3. Clinton SC, Newell A, Downey PA, Ferreira K. Pelvic girdle pain in the antepartum population.JWomens Health Phys Therap2017;41(2):102-25.

4. Vleeming A, Albert HB, Östgaard HC, Sturesson B, Stuge B. European guidelines on the diagnosis and treatment of pelvic girdle pain.Eur Spine J 2018;17(6):794-819.doi: 10.1007/s00586-008-0602-4

5. Bhardwaj A, Nagandla K. Musculoskeletal symptoms and orthopaedic complications in pregnancy: pathophysiology, diagnostic approaches and modern management. Postgrad Med J 2014;90(1066):450-60. doi: 10.1136/ postgradmedj-2013-132377.

6. Kanakaris NK, Roberts CS, Giannoudis PV. Pregnancy-related pelvic girdle pain: an update. BMC Med 2011;9:15. doi: 10.1186/1741-7015-9-15

7. Pierce H, Homer CSE, Dahlen HG, King J. Pregnancy-related lumbopelvic pain: listening to Australian women. Nurs Res Pract2012;2012:387428. doi: 10.1155/2012/387428.

8. Pennick, V, Liddle, SD.Interventions for preventing and treating pelvic and back pain in pregnancy. Cochrane Database of SystRev2013;(8):CD001139. doi:10.1002/14651858. cd001139.pub3

9. Walters C, West S, Nippita TA. Pelvic girdle pain in pregnancy. Aust J Gen Pract 2018;47(7):439-43. doi: 10.31128/AJGP-01-18-4467.
10. Björklund K, Bergström S, Lindgren PG, Ulmsten U. Ultrasonographic measurement of the symphysis pubis:a potential method of studying symphyseolysis in pregnancy. GynecolObstet Invest 1996;42(3):151-3.doi: 10.1159/000291932.

11. Albert H, GodskesenM,Westergaard J. Evaluation of clinical tests used in classification procedures in pregnancy-related pelvic joint pain. EurSpine J 2000;9(2):161-6.doi: $10.1007 / \mathrm{s} 005860050228$.

12. KristianssonP,Svärdsudd K, von SchoultzB.Serumrelaxin, symphyseal pain, and back pain during pregnancy. Am J ObstetGynecol 1996;175(5):1342-7.doi:10.1016/s00029378(96)70052-2

13. MacLennan AH. The role of the hormone relaxin in human reproduction and pelvic girdle relaxation. Scand J RheumatolSuppl1991;88:7-15.

14. BjörklundK,BergströmS,NordströmML,Ulmsten U. Symphyseal distention in relation to serum relaxin levels and pelvic pain in pregnancy. ActaObstetGynecolScand2000;79(4):269-75.doi:10.1080/j.1600-0412.2000.079004269.x.

15. Schoellner C, SzökeN,Siegburg K.Pregnancy-associated symphysis damage from the orthopedic viewpoint--studies of changes of the pubic symphysis in pregnancy, labor and post partum. Z OrthopIhreGrenzgeb2001;139(5):458-62.doi: 10.1055/s-2001-17991.

16. BahlmannF,Merz E,Macchiella D,Weber G. Ultrasound imaging of the symphysis fissure for evaluating damage to the symphysis in pregnancy and postpartum. Z GeburtshilfePerinatol1993;197(1):27-30. 